Renata KRUKOWSKA

Andrzej ŚWIECA

Andrzej TUCKI

Uniwersytet Marii Curie-Skłodowskiej w Lublinie

\title{
KIM JEST TURYSTA W PARKU NARODOWYM? WYNIKI BADAŃ ANKIETOWYCH Z ROZTOCZAŃSKIEGO PARKU NARODOWEGO
}

\section{Wprowadzenie}

W ramach wciąż rosnącej urbanizacji i industrializacji obserwuje się wzrost zapotrzebowania u społeczeństw na wypoczynek poza miejscem stałego zamieszkania i pracy. Coraz więcej uwagi poświęca się także wpływowi rekreacji na świeżym powietrzu (ŚWIECA 2006, KAPLAN 1995, BELL i in. 2009) i kontaktu z naturą (WDOWIAK, TUCKI, red. 2015) na zdrowie fizyczne i psychiczne człowieka. Miejsce zaspokajania zgłaszanych potrzeb to głównie tereny otwarte, zielone, lasy, a także obszary o cennych walorach przyrodniczych objęte ochroną $\mathrm{w}$ formie parków narodowych.

$\mathrm{W}$ polskiej literaturze przedmiotu zagadnienia związane z różnymi aspektami dotyczącymi obecności turystów w parkach narodowych omawiano na przykładach pojedynczych obiektów, np. Magurskiego Parku Narodowego (MROCZKA, ADAMSKI 2010), Tatrzańskiego Parku Narodowego (HIBNER 2012), Pienińskiego Parku Narodowego (KOLASIŃSKA 2010) lub parków z obszaru Karpat Zachodnich (KRAKOWIAK 2000) czy Polski północno-zachodniej (MATUSZEWSKA 2002). Liczba turystów oraz sposób ich zachowania w największym stopniu oddziałują na funkcjonowanie turystyki na obszarze parku 
narodowego. Coraz częściej nadmierny ruch turystyczny jest przyczyną konfliktu związanego z dwiema zasadniczymi funkcjami parków - ochronną i turystyczną. Ten problem przedstawiany był w literaturze naukowej na przykładzie wybranych parków, m.in.: Słowińskiego (MATUSZEWSKA 2008), Tatrzańskiego (CIAPAŁA i in. 2010), Wielkopolskiego (KASPRZAK, RASZKA 2003) czy Biebrzańskiego i Narwiańskiego (KOWALCZYK 2003).

Duże znaczenie ma określenie kierunków rozwoju oraz udostępniania turystycznego parków, aby obszary te mogły realizować swoje funkcje, a wzrost ruchu turystycznego nie doprowadził do degradacji ich walorów. Główną rolę spełnia tu analiza ruchu turystycznego i badanie opinii turystów. Należy jednak pamiętać, że ocena ruchu turystycznego stanowi jeden z trudniejszych obszarów badań nad turystyką (FINN i in. 2000).

Roztoczański Park Narodowy (RPN) jest jednym z ważniejszych produktów turystycznych na Roztoczu (BRZEZIŃSKA-WÓJCIK, ŚWIECA 2014). Wybrane aspekty turystycznej eksploracji Parku oraz jego bezpośredniego sąsiedztwa analizowano w opracowaniu A. ŚWIECY i in. (2016). Celem niniejszego opracowania jest przedstawienie charakteru ruchu turystycznego na terenie RPN oraz analiza percepcji Parku w opinii odwiedzających.

\section{Materiał i metody}

Prezentowane $\mathrm{w}$ pracy zagadnienia obejmują turystyczne wykorzystanie przyrodniczych i kulturowych walorów RPN. Jedną z podstawowych metod badawczych jest statystyka biletów wstępu do parku narodowego (ALEJZIAK 2009). Wstępny materiał analityczny dotyczący ruchu turystycznego pozyskano $\mathrm{w}$ oparciu o monitoring ruchu turystycznego, związany z pobieraniem opłat za wstęp. Uzupełnieniem wielkości i zmienności ruchu turystycznego na obszarze RPN były badania pierwotne - monitoring ruchu w Parku w latach 2006-2011. Liczenie odbywało się w miesiącach o największym natężeniu ruchu turystycznego na najchętniej odwiedzanych szlakach pieszych i rowerowych, w miejscach największej koncentracji ruchu turystycznego. Badania pomiarowe prowadzono $\mathrm{w}$ cyklach tygodniowych $\mathrm{i}$ weekendowych, jednocześnie w kilku miejscach na terenie Parku. Równolegle prowadzono jakościowe badania ankietowe wśród turystów go odwiedzających.

W pracy przedstawiono wyniki 478 ankiet przeprowadzonych w 2011 roku w dniach: 29.04.-03.05. (5 dni obejmujących długi weekend majowy), 
20-26.06. (7 dni - długi weekend z Bożym Ciałem), 11-17.07. (7 dni), 0915.08. (7 dni - długi weekend ze świętem Wniebowstąpienia NMP). Badania prowadzono w czterech punktach: parking przy Ośrodku Edukacyjno-Muzealnym, ścieżka na Bukową Górę, ścieżka rowerowa do Florianki oraz kąpielisko na stawach Echo.

\section{Charakterystyka obszaru badań}

Roztoczański Park Narodowy wraz z otuliną położony jest w województwie lubelskim, na terenie pięciu gmin powiatu zamojskiego (Zwierzyniec, Szczebrzeszyn, Adamów, Zamość, Krasnobród) oraz dwóch gmin powiatu biłgorajskiego (Jozefów, Tereszpol). Obszar Parku, o powierzchni 8482,83 ha, położony jest głównie w gminie Zwierzyniec. Pod względem fizycznogeograficznym Park zajmuje tereny Roztocza Środkowego.

Zasoby przyrodnicze RPN reprezentują elementy krajobrazu z charakterystycznymi obiektami geologicznymi i formami rzeźby terenu, zjawiskami wodnymi i światem organicznym. Są to głównie zbiorowiska leśne oraz otwarte harmonijne krajobrazy kulturowe (SWIECA i in. 2013). Znaczna część powierzchni Parku (około 86\%) objęta jest ochroną czynną. Najcenniejsze pod względem przyrodniczym są obszary Bukowej Góry, Czerkies, Jarugi, Międzyrzeki oraz Nart objęte ochroną ścisłą. Pod względem ilościowym w RPN przeważają obiekty przyrody ożywionej, związane głównie ze zbiorowiskami leśnymi (95,5\%). Dominujący udział w zajmowanej powierzchni mają drzewostany iglaste: sosnowe $(55,8 \%)$ oraz jodłowe $(19,4 \%)$. Wśród gatunków liściastych największą powierzchnię zajmują drzewostany bukowe (17,4\%). Najcenniejsze zbiorowiska leśne to bór jodłowy i buczyna karpacka - zespoły charakterystyczne dla regla dolnego Karpat. Wody w RPN i jego okolicy to przede wszystkim rzeki Wieprz, Świerszcz i Szum oraz sztuczne zbiorniki - stawy Echo, na których funkcjonuje kąpielisko.

Główną bazą do poznawania Parku jest leżąca w jego centrum miejscowość Zwierzyniec, która swoje istnienie zawdzięcza rodzinie Zamoyskich. W czasie ponad 350 lat funkcjonowania pod zarządem Ordynacji Zamojskiej miasto pełniło przede wszystkim funkcję rekreacyjno-wypoczynkową, a także osady przemysłowej i urzędniczej (KRUKOWSKA, JóźWIK 2004). Układ przestrzenny miasta, z zadrzewieniami, wodami i ciągami komunikacyjnymi, pochodzi z wieków XVIII-XIX i jest pozostałością dawnej rezydencji Za- 
moyskich z końca XVI wieku. Wśród obiektów zabytkowych Zwierzyńca większość związana jest z rodziną Zamoyskich: budynki zarządu dóbr ordynacji - Pałac Administracji i Pałac Ordynata (obecnie Zespół Szkół Drzewnych i Ochrony Środowiska), Pałac Plenipotenta (dziś siedziba Dyrekcji Roztoczańskiego Parku Narodowego), barokowy kościół pw. św. Jana Nepomucena (zbudowany na wyspie stawu w centrum miejscowości) oraz budynki browaru (SKOWRONEK 2005). Z organizowanych tu imprez kulturalnych należy wspomnieć o Letniej Akademii Filmowej (obywająca się od 2000 r.). Ponadto w pobliżu Roztoczańskiego Parku Narodowego znajdują się liczne centra i ośrodki krajoznawcze - w tym najcenniejszy - Zamość, ze starówką wpisaną na Listę Światowego Dziedzictwa Kulturowego i Przyrodniczego UNESCO.

Roztoczański Park Narodowy jest jednym z trzech parków wyżynnych, obok Ojcowskiego i Świętokrzyskiego, o średnim stopniu użytkowania turystycznego, wyróżniającym się stosunkowo dobrym zagospodarowaniem oraz średnim poziomem eksploatacji i penetracji przestrzeni (LISZEWSKI 2009). Poznanie walorów Parku umożliwiają szlaki turystyczne, rowerowe i ścieżki edukacyjne. Największe znaczenie w zakresie rozwoju turystyki poznawczej na terenie Roztoczańskiego Parku Narodowego ma dziewięć ścieżek edukacyjnych (na Bukową Górę, na Piaseczną Górę, po wydmie do stawów Echo, do stawów Echo, do Wzgórza Polak, do Wojdy, aleją Aleksandry Wachniewskiej oraz dendrologiczna i krajobrazowa we Floriance) o łącznej długości 17,7 km. W obrębie Parku przebiega pięć tranzytowych szlaków turystycznych pieszych (Centralny, Krawędziowy, Roztoczański, Partyzancki, Obwodnica RPN im. Aleksandry Wachniewskiej) o długości $53,3 \mathrm{~km}$ na terenie RPN. Cztery trasy rowerowe (do Florianki, Centralny Szlak Rowerowy, Wzgórze Polak - pogranicze regionów, Trasa Rowerowa Ziemi Józefowskiej) mają w Parku łączną długość 17,5 km. Ponadto w granicach Roztoczańskiego Parku Narodowego wytyczono trasy, które można pokonywać na koniku polskim. Są to: trasa rowerowa do Florianki, ścieżka krajobrazowa we Floriance, część szlaku krawędziowego Roztocza oraz tzw. droga tereszpolska (BRZEZIŃSKA-WÓJCIK, BARANOWSKA 2012). Głównym punktem węzłowym Parku jest Ośrodek Edukacyjno-Muzealny, w którym funkcjonuje punkt informacji turystycznej oraz biblioteka z czytelnią.

Baza noclegowa w Roztoczańskim PN i jego otulinie jest zróżnicowana pod względem charakteru. Większość obiektów zlokalizowana jest w gminie Zwierzyniec. Jak wynika z danych statystycznych (tab. 1), w roku 2014 funkcjonowały tam 42 obiekty noclegowe zbiorowego zakwaterowania, które 
dysponowały liczbą 1694 miejsc noclegowych, w tym: sześć ośrodków wczasowych (357 miejsc), trzy obiekty hotelowe (127), dwa pensjonaty (86), cztery szkolne schroniska młodzieżowe (253), cztery ośrodki szkoleniowo-wypoczynkowy (293), pole biwakowe (50), schronisko młodzieżowe (30) oraz 16 pozostałych obiektów (268 miejsc). W obiektach zbiorowego zakwaterowania w roku 2014 nocowało około 27,5 tys. turystów, a udzielono blisko 81 tys. noclegów.

Tab. 1. Obiekty zbiorowego zakwaterowania i ich wykorzystanie w rejonie RPN w $2014 \mathrm{r}$.

\begin{tabular}{|l|c|c|c|c|}
\hline Jednostka administracyjna & $\begin{array}{c}\text { Liczba } \\
\text { obiektów }\end{array}$ & $\begin{array}{c}\text { Miejsca } \\
\text { noclegowe }\end{array}$ & $\begin{array}{c}\text { Korzystający } \\
\text { z noclegów }\end{array}$ & $\begin{array}{c}\text { Udzielone } \\
\text { noclegi }\end{array}$ \\
\hline Gmina i miasto Zwierzyniec & 19 & 578 & 8034 & 17582 \\
\hline Gmina Krasnobród & 16 & 834 & 16209 & 47893 \\
\hline Gmina Józefów & 5 & 172 & 870 & 7635 \\
\hline Gmina Tereszpol & 1 & 10 & 50 & 95 \\
\hline Gmina Szczebrzeszyn & 1 & 100 & 2185 & 7788 \\
\hline Łącznie & 42 & 1694 & 27348 & 80993 \\
\hline
\end{tabular}

Źródło: opracowanie własne na podstawie (GUS, 2015).

Uzupełnieniem bazy noclegowej zbiorowego zakwaterowania są pokoje gościnne i kwatery agroturystyczne. Obiekty te prowadzone są głównie w najbliższym otoczeniu Parku, najliczniej w gminie Zwierzyniec (70 pokoi, 41 kwater) oraz w gminach Adamów (9 kwater) i Tereszpol (3 kwatery) (Statystyczne... 2012).

Spośród urządzeń gastronomicznych w rejonie Roztoczańskiego Parku Narodowego najliczniejszą grupę stanowią zakłady żywieniowe, zlokalizowane w Zwierzyńcu (restauracje, bary i jadłodajnie), Górecku Kościelnym (karczma), Guciowie (zagroda) i w Kaczórkach (zajazd). Uzupełniają je punkty małej gastronomii w Zwierzyńcu i Bondyrzu.

\section{Ruch turystyczny w RPN}

Ewidencja ruchu turystycznego na podstawie liczby sprzedanych biletów wstępu na ścieżki w Roztoczańskim Parku Narodowym i do Ośrodka Edukacyjno-Muzealnego RPN w latach 2002-2014 wskazuje, że przeciętnie w ciągu roku przebywa tam około 40 tys. osób, przy stosunkowo dużej zmienności z roku na rok, od blisko 27 tys. do około 50 tys. odwiedzających 
(rys. 1). W strukturze odwiedzających przeważają osoby przebywające $\mathrm{w}$ grupach - przeciętnie prawie 28 tys. (71\%). Odwiedzający indywidualni - około 11,5 tys. (29\% - przeciętnie co trzecia osoba) - to głównie osoby dorosłe.

Ruch turystyczny w Roztoczańskim Parku Narodowym i Ośrodku Edukacyjno-Muzealnym wykazuje z miesiąca na miesiąc duże zróżnicowanie wielkościowe. Stosunkowo niewielkie jego natężenie obserwuje się od listopada do marca. W tych miesiącach $w$ wieloleciu 2006-2014 przeciętna liczba odwiedzających wynosiła od około 270 do 820 osób. Znaczne ożywienie ruchu turystycznego odnotowano szczególnie w maju (7219 osób) i czerwcu (7112). Frekwencja w tych dwóch miesiącach stanowi łącznie około 40\% wielkości rocznej, przy czym dominują wtedy turyści w zorganizowanych grupach. Analiza wielkości miesięcznych wskazuje, że jedynie w lipcu i sierpniu odwiedzający w grupach (odpowiednio 42,7\% i 29,7\%) ustępują turystom indywidualnym. Dla pozostałych 10 miesięcy typowa jest zasada dominacji przyjeżdżających do RPN w grupach (od 69,1\% do 91,1\% ogółu turystów).

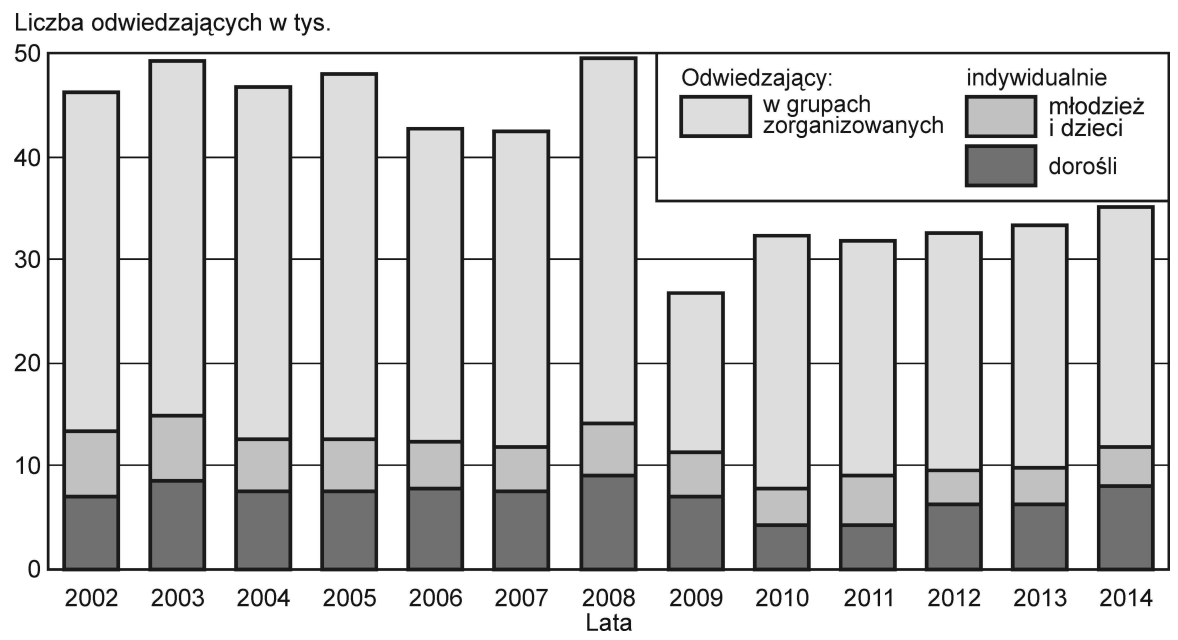

Rys. 1. Liczba biletów sprzedanych na ścieżki w RPN oraz do OEM w latach 2002-2014 Źródło: opracowanie własne na podstawie danych RPN

Z przeprowadzonych badań ruchu turystycznego (na podstawie sprzedanych biletów oraz monitoringu) wynika, że liczba sprzedawanych biletów wstępu do Parku stanowi 35-40\% całego ruchu turystycznego w RPN. 
W związku z powyższym na podstawie obliczonych dla okresów 2006-2010 i 2002-2010 wielkości ruchu turystycznego (odpowiednio około 39 tys. i 43 tys.) można oszacować wielkość przeciętnego w ciągu roku ruchu turystycznego w Parku na poziomie 95-120 tys. osób.

\section{Turyści w RPN - wyniki badań ankietowych}

Badaniami ankietowymi w 2011 roku objęto 478 osób, wśród których 52,5\% stanowili mężczyźni, a 47,5\% kobiety. Ankietowanych podzielono na sześć grup wiekowych: do 20 roku życia (12,3\%), 21-30 lat (28,0\%), 31-40 lat $(27,0 \%), 41-50$ lat $(15,7 \%), 51-60$ lat $(10,5 \%)$ oraz 61 lat i więcej (6,5\%). Średnia wieku respondentów wyniosła 36 lat. Większość (56,3\%) deklarowała posiadanie wyższego wykształcenia. Przeprowadzona analiza wskazuje, że spośród uwzględnionych 478 ankietowanych zdecydowana większość (476 osób) pochodziła z Polski. Dominowali (58\%) mieszkańcy województwa lubelskiego, spośród 242 respondentów większość mieszkała w Lublinie (31\%), Zamościu (17\%) oraz powiecie biłgorajskim (11\%) (rys. 2).

W grupie 234 ankietowanych pochodzących spoza regionu, byli mieszkańcy z województw: mazowieckiego (38\%; pochodzący głównie z Warszawy), podkarpackiego (13\%) i śląskiego (11). W grupie tej zabrakło jedynie reprezentantów województwa zachodniopomorskiego (rys. 2).

Mniej więcej co piąty ankietowany był odwiedzającym jednodniowym. Spośród osób, które przyjechały do RPN na dłużej, ponad połowa (53\%) deklarowała pobyt weekendowy, a nieco mniej badanych $(47 \%)$ zostawało dłużej.

Badania ankietowe przeprowadzone $\mathrm{w}$ aspekcie częstotliwości przyjazdu do Parku wykazały w 2011 roku, że 58\% respondentów przyjechało do niego po raz pierwszy, a $42 \%$ odwiedziło go ponownie. Spośród osób odwiedzających Park po raz kolejny, ponad połowa (54\%) przyjeżdżała tu jeden raz $\mathrm{w}$ roku. Miesiącami natężonych przyjazdów turystycznych były lipiec i sierpień ( $53 \%$ wskazań) oraz maj i czerwiec ( $28 \%$ wskazań).

Zdecydowanie najważniejszym motywem odwiedzin Parku był wypoczynek (45\% wskazań), kolejno - wspólny wyjazd rodzinny (23\% wskazań) i towarzyski (18\% wskazań). Prawie $74 \%$ badanych jako główny cel podróży obrało RPN. Wśród turystów najczęstszą formą pozyskiwania informacji o nim przed wyjazdem był Internet - $42 \%$ wskazań, a także znajomi - $36 \%$ 
odpowiedzi. W czasie pobytu w RPN 55\% ankietowanych deklarowało, że korzystają z materiałów drukowanych (map i przewodników). Odwiedzający Park w dużym stopniu wykorzystywali jego infrastrukturę - 56\% ankietowanych deklarowało korzystanie ze ścieżek i szlaków w RPN. Obiekty najczęściej odwiedzane przez respondentów to barokowy kościólek na wodzie (na wyspie) - 50\%, oraz stawy Echo - $44 \%$.

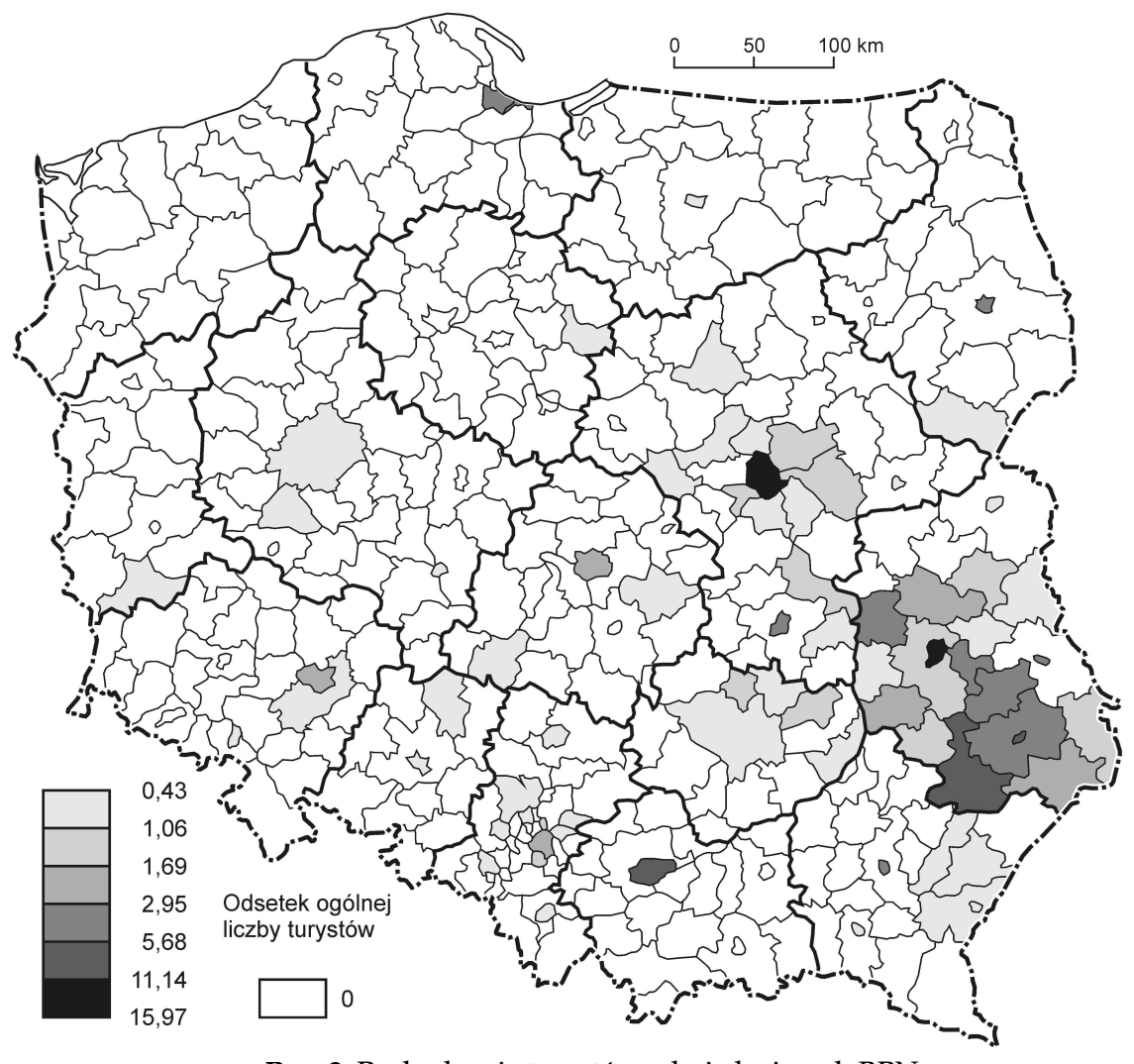

Rys. 2. Pochodzenie turystów odwiedzających RPN

(na podstawie badań ankietowych z 2014 r.)

Źródło: opracowanie własne na podstawie badań terenowych

Prawie co drugi ankietowany (48\%) korzystał z małych obiektów noclegowych sfery prywatnej (gospodarstwa agroturystyczne $-28 \%$, pokoje gościnne - 20\%). Rzadziej korzystano z usług obiektów komercyjnych - z pensjonatów (16\%) oraz z ośrodków wypoczynkowych $(8 \%)$. Niespełna $13 \%$ respondentów wskazało, że nocowało u rodziny bądź znajomych (rys. 3). 


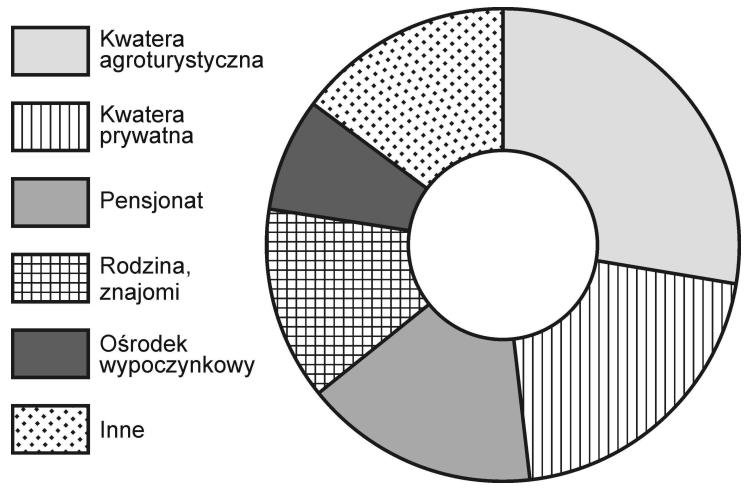

Rys. 3. Obiekty noclegowe, z których korzystali ankietowani podczas pobytu w RPN w $2014 \mathrm{r}$.

Źródło: opracowanie własne na podstawie badań terenowych

Turyści w większości pozytywnie oceniają jakość infrastruktury turystycznej. Bazę noclegową „bardzo dobrze" i „dobrze" oceniło 84\% respondentów. Podobnie turyści ocenili RPN pod względem infrastruktury turystycznej (szlaki i ścieżki dydaktyczne) - „bardzo dobrze” i „dobrze” oceniło ją 86\% badanych. Nieco gorzej wypowiadają się na temat jakości usług gastronomicznych, tj. $46 \%$ "dobrze" i $27 \%$ "przeciętnie". W ocenie stanu czystości RPN prawie połowa ankietowanych (46\%) przyznała ocenę „dobrą".

Ważnym aspektem badań było wskazanie wizerunku oraz skojarzeń, jakie z Parkiem mają turyści go odwiedzający (rys. 4). Przed przyjazdem do RPN respondenci kojarzyli miejsce przede wszystkim z przyrodą (32\% wskazań) i lasami (31\%), mniej osób (15\%) ze stawami Echo.

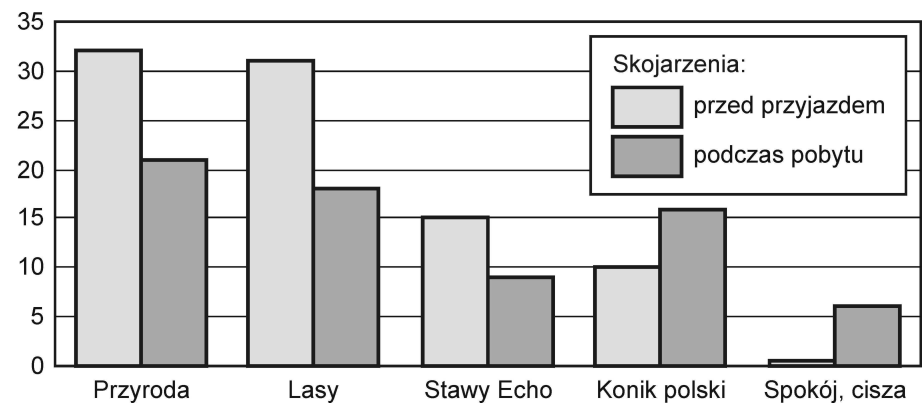

Rys. 4. Skojarzenia ankietowanych z RPN przed przyjazdem oraz w czasie pobytu w $2014 \mathrm{r}$.

Źródło: opracowanie własne na podstawie badań terenowych 
Po pobycie w Parku odpowiedzi były dużo bardziej zróżnicowane i szczegółowe. Ankietowani nadal wskazywali na przyrodę, lasy i stawy Echo, ale liczba odpowiedzi była mniejsza i stanowiła odpowiednio: 21\%, 18\% i 9\%. Zwiększyła się liczba skojarzeń, które są związane z symbolem Parku, czyli konikiem polskim (16\%). Ponadto zanotowano bardzo duży wzrost liczby odpowiedzi wskazujących na skojarzenia pobytu w Parku ze spokojem i ciszac - wzrost z $0,5 \%$ do $6 \%$ odpowiedzi. W przeprowadzonej ankiecie turyści podawali także miejsca i obiekty, które w ich opinii są najatrakcyjniejsze. Wśród przyrodniczych elementów potencjału turystycznego najlepiej oceniono stawy Echo (21\%), natomiast z walorów kulturowych za najatrakcyjniejszy obiekt uznano kościół na wodzie (29\%).

\section{Podsumowanie i wnioski}

Natężenie ruchu turystycznego i jego struktura w Roztoczańskim Parku Narodowym wykazuje znaczne zróżnicowanie. W oparciu o istniejący materiał badawczy stwierdzono, że w okresie od maja do czerwca oraz we wrześniu dominuje turystyka zorganizowana - wycieczki (głównie młodzieży), a w czasie dni wolnych - aktywna turystyka w grupach rodzinnych.

Wśród osób ankietowanych odwiedzających RPN dominowały osoby od 21 do 40 roku życia (55\%), a średnia ich wieku wyniosła 36 lat. W badanej grupie turystów dominowali (58\%) mieszkańcy województwa lubelskiego, głównie Lublina (31\%) i Zamościa (17\%). Roztoczański Park Narodowy jako główny cel podróży obrało prawie $74 \%$ respondentów. Jak wynika z ich opinii, najistotniejszym elementem związanym $z$ wypoczynkiem na tym obszarze jest przyroda. Bogate walory przyrodnicze i umiejętne wkomponowanie niezbędnego zagospodarowania stwarza przestrzeń turystyczną przyjazną zarówno dla człowieka, jak i dla środowiska.

Najbardziej pozytywny wpływ na atrakcyjność Parku ma wyjątkowość chronionego terenu, duża liczebność szlaków i ścieżek przyrodniczych oraz obecność w jego obrębie zabytków. Rozwinięta infrastruktura turystyczna, dobrze oceniana przez odwiedzających, daje podstawę do rozwoju działalności edukacyjnej i ekoturystyki. Należy podkreślić, iż w Parku przyrodnicza turystyka edukacyjna powinna mieć charakter powszechny. Może nie wszyscy powinni i mogą brać udział w jej tzw. zorientowanej formie, ale każdemu należałoby umożliwić uczestnictwo w tego rodzaju turystyce, która poprzez zabawę uczyłaby szacunku do przyrody. 
Obszar ten jest również idealnym miejscem do wypoczynku dla turystów. Turystyka wywiera największą presję na Park w rejonie Zwierzyńca (duże zagęszczenie ścieżek). Ponadto $\mathrm{w}$ sezonie występuje $\mathrm{w}$ RPN bardzo wyraźna koncentracja ruchu turystycznego nad stawami Echo, miejscu turystyki (rekreacji) weekendowej.

Wyniki badań potwierdziły dużą rolę Internetu w podejmowaniu decyzji o wyborze odwiedzanego miejsca. Jednocześnie udokumentowały duże znaczenie drukowanych materiałów - map i przewodników - wykorzystywanych podczas eksploracji obszaru Roztoczańskiego Parku Narodowego.

\section{Bibliografia}

ALEJZIAK W., 2009, TelSKARTC - nowa metoda badań i pomiaru wielkości ruchu turystycznego, „Folia Turistica", 21, s. 95-144.

Bell S., Simpson M., Tyrvainen L., Sievanen T., Proebstl U. (red.), 2009, European forest recreation and tourism: a handbook, Taylor and Francis, Londyn.

BRZEZIŃSKA-WÓJCIK T., BARANOWSKA M., 2012, Możliwości rozwoju turystyki konnej w województwie lubelskim w kontekście uwarunkowań przyrodniczych, „Polish Journal of Sport and Tourism”, 19, 4, s. 256-270.

BRZEZIŃSKA-WÓJCIK T., ŚWIECA A., 2014, The current state and perspectives of development of tourism products in Roztocze in the context of environmental and educational tourism, "Scientific Journal", 836, „Economic Problems of Tourism”, 4(28), s. 379-399.

CIAPAŁA S., ZIELONKA T., KMIECIK-WRÓBEL J., 2010, Metody zapobiegania nielegalnej dyspersji turystów $i$ związanej z nią erozji gleby w Tatrzańskim Parku Narodowym, „Folia Turistica”, 22, s. 67-89.

FinN M., ElLiOTT-White M., WALTON M., 2000, Tourism and leisure research methods, Longman, London.

HIBNER J., 2012, Zróżnicowanie ruchu turystycznego w Tatrzańskim Parku Narodowym na wybranych przykładach, [w:] A. Richling, Ł. Zbucki (red.), Rekreacja w krajobrazach o wysokim potencjale, Problemy Ekologii Krajobrazu, XXXIV, s. 41-47.

KAPLAN S., 1995, The restorative benefits of nature: toward and integrative framework, „Journal of Environmental Psychology", 15, s. 169-182.

KASPRZAK K., RASZKA B., 2003, Konflikt funkcji i użytkowania na przykładzie wykorzystania rekreacyjnego Jeziora Dymaczewskigo (Rynna Witobelsko-Dymaczewska) w Wielkopolskim Parku Narodowym, [w:] M. Pietrzak (red.), Krajobraz - turystyka - ekologia, „Problemy Ekologii Krajobrazu”, XI, s. 13-37.

KOLASIŃSKA A., 2010, Postawy turystów w odniesieniu do ochrony przyrody w świetle badań ankietowych na przykładzie Pienińskiego Parku Narodowego, „Folia Turistica”, 22, s. 207-216.

KOWALCZYK A., 2003, Bariery rozwoju turystyki na obszarze i w otulinie Biebrzańskiego Parku Narodowego i Narwiańskiego Parku Narodowego, [w:] M. Pietrzak (red.), Krajobraz - turystyka - ekologia, „Problemy Ekologii Krajobrazu", XI, s. 103-110.

KRAKOWIAK B., 2000, Charakterystyka ruchu turystycznego w parkach narodowych Karpat Zachodnich - typy funkcjonalne parkóww, „Turyzm”, 10, 1, s. 5-37.

KRUKOWSKA R., JÓŹWIK M.J., 2004, Walory turystyczne Zwierzyńca i okolic, [w:] R. Dobrowolski, S. Terpiłowski (red.), Stan i zmiany środowiska geograficznego wybranych regionów wschodniej Polski, Wyd. Uniwersytetu Marii Curie-Skłodowskiej, Lublin, s. 147-152. 
LISZEWSKI S., 2009, Przestrzeń turystyczna parków narodowych w Polsce, [w:] B. Domański, W. Kurek (red.), Gospodarka i przestrzeń, IGiGP Uniwersytetu Jagiellońskiego, Kraków, s. 187-200.

MATUSZEWSKA D., 2002, Ochrona przyrody i turystyka w Stowińskim Parku Narodowym w opiniach turystów, [w:] J. Partyka (red.), Użytkowanie turystyczne parków narodowych, Instytut Ochrony Przyrody PAN, Ojcowski Park Narodowy, Ojców, s. 352-357.

MATUSZEWSKA D., 2008, Spotecznie uwarunkowanie planowania i zarządzania zrównoważonym rozwojem turystyki w parkach narodowych na przykładzie Stowińskiego Parku Narodowego, [w:] G. Gołembski (red.), Turystyka jako czynnik wzrostu konkurencyjności regionów w dobie globalizacji, Akademia Ekonomiczna w Poznaniu, Poznań, s. 336-350.

MROCZKA A., ADAMSKI P., 2010, Dzienny rozkład ruchu turystycznego w wybranych rezerwatach przyrody i Magurskim Parku Narodowym, „,Folia Turistica”, 22, s. 91-105.

SKOWRONEK E., 2005, Wptyw działalności gospodarczej Ordynacji Zamojskiej na ksztatt dziedzictwa kulturowego i przyrodniczego Zamojszczyzny, [w:] E. Skowronek (red.), Wptyw dziatalności gospodarczej wielkich majątków ziemskich na stan wspótczesny dziedzictwa przyrodniczego i kulturowego, Wyd. Uniwersytetu Marii Curie-Skłodowskiej, Lublin, s. 19-36.

Statystyczne Vademecum Samorządowca 2012, Gmina Miejsko-Wiejska Zwierzyniec, Urząd Statystyczny w Lublinie, www.stat.gov.pl (dostęp: 12.06.2013)

ŚWIECA A., 2006, Aktywne formy wypoczynku - wyzwaniem wspótczesnego cztowieka, [w:] A. Świeca, K. Kałamucki (red.), Turystyka aktywna i jej rozwój na Roztoczu - regionie pogranicza, Kartpol, Lublin, s. 13-20.

ŚWIECA A., BRZEZIŃSKA-WÓJCIK T., GRABOWSKI T., KAŁAMUCKI K., KRUKOWSKA R., TUCKI A., 2013, Turystyka i edukacja, [w:] R. Reszel, T. Grądziel (red.), Roztoczański Park Narodowy. Przyroda i człowiek, Roztoczański Park Narodowy, Zwierzyniec, s. 219-230.

ŚWIECA A., KRUKOWSKA R., TUCKI A., GRABOWSKI T., 2016, Wybrane aspekty rozwoju ruchu turystycznego w Roztoczańskim Parku Narodowym, „Zeszyty Naukowe”: Ekonomiczne Problemy Ustug, Wyd. Naukowe Uniwersytetu Szczecińskiego, Szczecin (w druku).

WDOWIAK A., TUCKI A., (red.) 2015, Aspekty środowiskowo-rekreacyjne i prawne zdrowia człowieka, Międzynarodowe Towarzystwo Wspierania i Rozwoju Technologii Medycznej, Lublin. 